\title{
Thyroxine Binding Globulin Radioimmunoassay in Dried Blood Spotted on Filter Paper
}

\author{
By T. Torresani, Helena Krawczynska ${ }^{1}$ ) and Ruth Illig $^{2}$ ) \\ Department of Pediatrics, University of Zürich, Switzerland
}

(Received November 10, 1982/February 21, 1983)

Summary: A method is described for the determination of thyroxine binding globulin (TBG) in dried blood spotted on filter paper using reagents from a test kit for the measurement of TBG in plasma. By minor modifications of the recommended procedure it was possible to improve precision, sensitivity and tracer displacement. Appropriate TBG standard samples were prepared in 'artificial blood' consisting of a suspension of erythrocytes in buffer with bovine serum albumin $(50 \mathrm{~g} / 1)$. There is a good correlation between plasma TBG RIA results and blood spot TBG RIA results $(r=0.93)$. Attention must be paid to the stability of the TBG in blood: our experiments show a decrease of TBG content if filter paper cards with dried blood are stored longer than one month.

\section{Radioimmunoassay für Thyroxin bindendes Globulin in auf Filterpapier getrockneten Blutstropfen}

Zusammenfassung: Es wird eine Methode zur Bestimmung des Thyroxin bindenden Globulins (TBG) aus getrockneten Blutstropfen unter Verwendung von Reagentien aus einer Test-Packung zur Messung von TBG im Plasma beschrieben. Durch leichte Modifikation des empfohlenen Vorgehens war es möglich, die Präzision, die Empfindlichkeit und die Verdrängung des Tracers zu verbessern. Die TBG-Standard-Verdünnungen wurden in 'künstlichem Blut', das aus einer Suspension von Erythrocyten in Puffer mit Rinderserumalbumin $(50 \mathrm{~g} / 1)$ besteht, hergestellt. Zwischen den Resultaten des TBG-RIA für Plasma und des TBG-RIA im getrockneten Blutstropfen wurde eine gute Korrelation $(r=0.93)$ gefunden. Aufmerksamkeit sollte der Stabilität von TBG im getrockneten Blut geschenkt werden: unsere Versuche haben eine Abnahme der TBG-Konzentrationen gezeigt, wenn die Filterpapiere mit dem getrockneten Blut länger als einen Monat gelagert werden.

\section{Introduction}

With the introduction of serial neonatal screening for congenital hypothyroidism, methods have been developed which allow the determination of thyrotropin (1) and thyroxine (2) in blood spots dried on filter paper. Blood sampling by heel puncture is easy to perform even in very small and young infants, and mailing and storage of filter paper cards is uncomplicated. Therefore, determinations in dried blood have also been applied to the measurement of other hor-

1) Visiting Fellow from Warszawa, Poland.

2) Supported by the Swiss National Science Foundation, Grant No. 3.984.080 and by HENNING Berlin. mones and substances such as "free thyroxine" (FT4) (3), 17- $\alpha$-hydroxy-progesterone $(4,5), \alpha$-fetoprotein (6) and TBG (7).

We present a method which we have developed for the determination of TBG in dried blood spotted on filter paper using commercially available reagents.

\section{Materials and Methods \\ Specimen collection}

Capillary blood obtained by heel prick, is spotted on filter paper (Schleicher \& Schuell No. 2992) and carefully dried at room temperature. Samples are sent to the laboratory by regular mail 
and thereafter kept in a plastic box at $4^{\circ} \mathrm{C}$ until analysed. Circles of $8 \mathrm{~mm}$ diameter are printed on one side of the filter paper in order to make sure that sufficient blood is collected.

\section{Blood spot TBG RIA}

For the determination of TBG in dried blood, the TBG-RIAcid procedurc for plasma TBG measurements (HENNING Berlin) was slightly modified. In this method, a double antibody/polyethylene glycol assisted separation of free and bound ${ }^{125} \mathrm{I}$ labelled TBG is used. The tracer has a specific activity of $1.295-1.85$ $\mathrm{TBq} / \mathrm{g}(35-50 \mathrm{Ci} / \mathrm{g})$ and a shelf life of $4-6$ weeks. Samples or standards, in the form of filter paper discs of $6.5 \mathrm{~mm}$ diameter, containing approximately $10 \mu \mathrm{l}$ blood, labelled TBG $(100 \mu \mathrm{l})$ and first antibody $(100 \mu \mathrm{l})$ are incubated simultaneously for $60 \mathrm{~min}$ utes, followed by the addition of the second antibody $(100 \mu \mathrm{l})$. After a further 60 minutes incubation, bound and free are separated by centrifugation for 20 minutes at $1600 \mathrm{~g}$. After decanting, the precipitates are washed with $2 \mathrm{ml}$ of distilled water, centrifuged and decanted again. The precipitates are then counted for one minute on an automatic $\gamma$-counter and the results evaluated by linear interpolation. The filter paper discs remain in the tube throughout the assay.

\section{Preparation of TBG standards in 'artificial blood'}

The concentrated standard is diluted to concentrations of 60,40 , 30,20 and $10 \mathrm{mg} / 1$ respectively, using $\mathrm{NaCl}$ solution $(154 \mathrm{mmol} / \mathrm{l}$ ) $\mathrm{mmol} / \mathrm{l})$ containing bovine serum albumin $(50 \mathrm{~g} / 1)$ and merthiolate $(0.1 \mathrm{~g} / \mathrm{l})$. To each standard solution an equal volume of washed erythrocytes is added. This suspension of erythrocytes ('artificial blood' with a hematocrit of 0.50 ), is spotted on filter paper and left to dry in air at $20-25^{\circ} \mathrm{C}$. Results are expressed as $\mathrm{mg} / \mathrm{l}$ of plasma.

\section{TBG RIA for plasma}

In order to test the validity of the blood spot TBG RIA, TBG concentrations of a number of patients were assayed in plasma as well as in dried blood spotted on filter paper. For the determination of plasma TBG, the TBG-RIAcid method (HENNING Berlin) was used without modification.

\section{Statistics}

Assay precision and sensitivity are calculated according to Rodbard (8). The significance of differences was estimated using the Wilcoxon signed rank test (paired samples) or the Wilcoxon ranksum test (non-paired samples).

\section{Results}

\section{Preparation of standards}

Because of the difficulties in obtaining blood without TBG an attempt was made to prepare 'artificial blood' which could be used as a diluent for standard TBG.

In preliminary experiments using the liquid system, we assayed TBG standard curves prepared from the supplied standard solutions and from sets of stand= ards diluted in a $\mathrm{NaCl}$ solution $(154 \mathrm{mmol} / \mathrm{l})$ containing either bovine $(50 \mathrm{~g} / \mathrm{l})$ or human serum albumin $(50 \mathrm{~g} / 1)$. Figure 1 shows that there is practically no difference between these standard curves. It was therefore decided to use a $\mathrm{NaCl}$ solution (154 $\mathrm{mmol} / \mathrm{l})$ containing bovine serum albumin $(50 \mathrm{~g} / 1)$

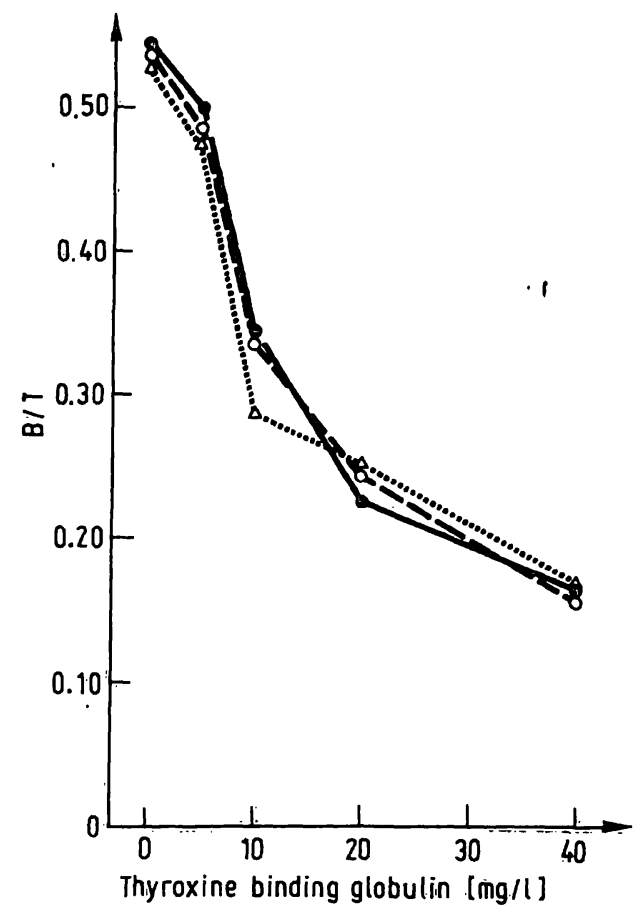

Fig. 1. Comparison of standard curves for the thyroxine binding globulin assay in plasma in phosphate buffer alone $(\Delta---\Delta)$, buffer with bovine serum albumin $(50 \mathrm{~g} / \mathrm{l})$ $(0-0)$ and with human serum albumin $(50 \mathrm{~g} / \mathrm{l})$ $(\mathrm{O}-\mathrm{-}-\mathrm{O})$.

for the preparation of 'artificial blood' for the dilution of standards (cf. Methods).

When standard curves were prepared with dried blood, displacement of TBG was lower than in the original liquid system. This is due to the fact that the filter paper discs contain approximately $5 \mu \mathrm{l}$ of plasma versus $10 \mu \mathrm{l}$ in the original ăssay system. In order to optimize the assay procedure, we tested the following modifications. A dilution curve for the TBG antibody (fig. 2) shows that the sensitivity increases with decreasing antibody concentration. We chose a dilution of $1: 2$ of the supplied antibody which gave the best results over the whole range of the standard curve. Thereafter, the influence of incubation time was studied. The manufacturers recommend 30 to $120 \mathrm{~min}$ for the first incubation. We tried different periods of 1 to 5 hours for the first incubation. Equilibrium of reaction was reached after one hour using the antibody diluted $1: 2$. The recommended time for the separation of bound and free TBG is 30 to 60 min. An increase up to two hours did not bring any advantage, particularly not with respect to precision of duplicates.

The supplied antibody solution contains normal rabbit serum. Since we diluted the antibody $1: 2$ it was necessary to adjust the amount of normal rabbit serum in order to restore ideal precipitating conditions. This adjustment, together with a slight prolon- 


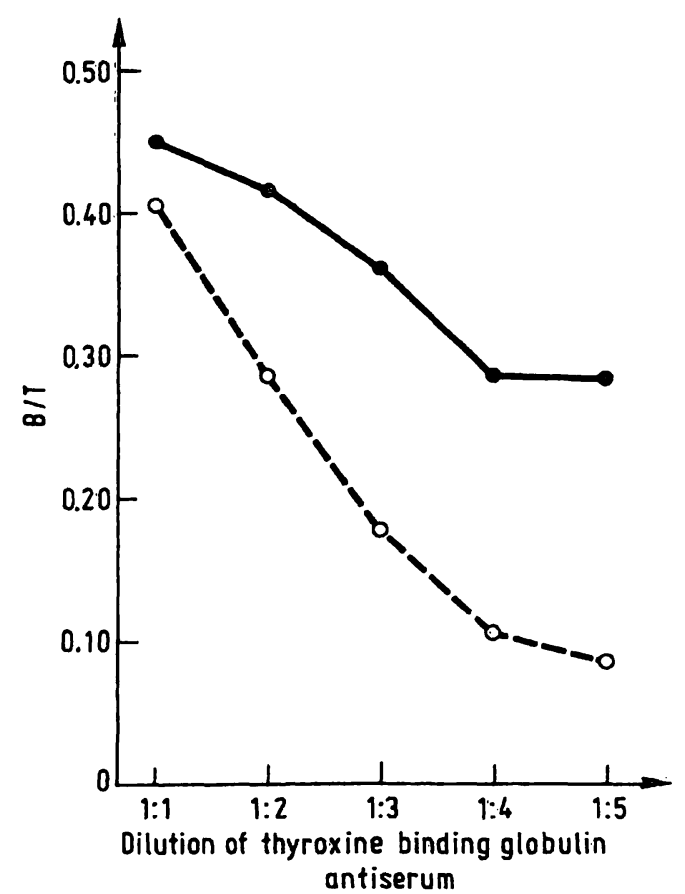

Fig. 2. Dilution curve for the supplied TBG antibody in the blood spot assay. Each dilution was assayed in the absence (O-O) and in presence of $10 \mathrm{mg} / \mathrm{l}$ TBG standard $(\mathrm{O}---\mathrm{O})$.

gation of centrifugation time $(20 \mathrm{~min}$ instead of 15 $\mathrm{min}$ ) led to a better precision in duplicates.

\section{Assay precision}

Intraassay coefficients of variation (C.V.) at TBG concentrations of $17.3 \mathrm{mg} / \mathrm{l}$ and $20.1 \mathrm{mg} / \mathrm{l}$ are $5.3 \%$ and $8.0 \%$ respectively $(n \neq 8)$. Interassay coefficients of variation at the same concentrations are $3.3 \%$ and $8.0 \%$ respectively $(n=8)$. The doses read at $80 \%$ and $50 \%$ of the standard curve in 8 consecutive assays are $8.64 \mathrm{mg} / \mathrm{l}(\mathrm{S} . \mathrm{D} . \equiv 0.9, \mathrm{C} . \mathrm{V} .10 .4 \%$ ) and $24.6 \mathrm{mg} / \mathrm{l}(\mathrm{S} . \mathrm{D} .=3.7, \mathrm{C} . \mathrm{V} .14 .8 \%)$ respectively.

\section{Assay sensitivity}

The sensitivity of the TBG blood spot RIA read from the standard curve at a point calculated as $\mathrm{B}_{0}-2 \mathrm{SD}$ is $1.83 \mathrm{mg} / \mathrm{l}(\mathrm{n}=10$, $\mathrm{SD} 0.65)(8)$.

\section{Assay validity}

In 30 patient samples, TBG was measured in plasma as well as in dried blood spots. The correlation between the two methods was statistically significant; the correlation coefficient was 0.9381 ; the regression equation is $y=0.884 x+3.084$ where $y$ represents the blood spot TBG concentration and $x$ the plasma TBG concentration.

\section{Stability of $T B G$}

Problems were encountered with the stability of TBG in blood spotted on filter paper. Table 1 shows the mean value and range for a group of 19 determinations of.TBG in plasma and in dried blood, measured soon after blood sampling. There is a good correlation between these measurements. In contrast to what happens with thyrotropin in dried blood spots (1), storage at $4{ }^{\circ} \mathrm{C}$ over a period of 5 months led to a significant loss of TBG in dried blood from patients $(p<0.0002)$. Similarly, the stability of standard TBG in 'artificial blood' was tested. The influence of storage on TBG concentrations is shown in table 2. If the TBG concentration in dried blood

Tab. 1. Correlation of TBG results $(\mathrm{mg} / \mathrm{l})$ measured in plasma and in dried blood spots and the effect of 5 months storage at $4{ }^{\circ} \mathrm{C}$ on TBG concentrations in 19 dried blood samples.

\begin{tabular}{lllll}
\hline & $\begin{array}{l}\text { TBG in } \\
\text { plasma } \\
\text { Dec 81 }\end{array}$ & $\begin{array}{l}\text { TBG in } \\
\text { blood spot } \\
\text { Dec 81 }\end{array}$ & $\begin{array}{l}\text { TBG in } \\
\text { blood spot } \\
\text { Apr 82 }\end{array}$ & $\begin{array}{l}\text { Blood spot: } \\
\text { Difference } \\
\text { Dec 81-Apr 82 }\end{array}$ \\
\hline $\begin{array}{l}\text { X } \\
\text { Range }\end{array}$ & $\begin{array}{l}30.9 \\
19-76\end{array}$ & $\begin{array}{l}30.2 \\
19-70\end{array}$ & $\begin{array}{l}23.1 \\
13-44\end{array}$ & $\mathrm{p}<0.0002$ \\
\hline & & $0.9413^{*}$ & $0.7710^{*}$ & \\
& & &
\end{tabular}

* Correlation coefficient for blood spot vs. plasma

Tab. 2. TBG concentration ( $\mathrm{mg} / \mathrm{l}$ plasma) in fresh blood spots of a patient read from standard curves prepared by measuring TBG standards in 'artificial blood'. The standards were stored at $4^{\circ} \mathrm{C}$ for 2 days, 1 month and 3 months, and at $-20^{\circ} \mathrm{C}$ for 1 month.

\begin{tabular}{lcccc}
\hline \multicolumn{5}{c}{ Storage time and temperature } \\
& 2 days & 30 days & 30 days & 90 days \\
& $4^{\circ} \mathrm{C}$ & $4{ }^{\circ} \mathrm{C}$ & $-20^{\circ} \mathrm{C}$ & $4{ }^{\circ} \mathrm{C}$ \\
\hline$\overline{\mathrm{x}}$ & 18.29 & 18.50 & 18.50 & 22.21 \\
$\mathrm{SD}$ & 1.11 & 1.00 & 2.02 & 1.55 \\
$\mathrm{n}$ & 7 & 4 & 6 & 7 \\
\hline Difference from 2 days & & & \\
storage at $4{ }^{\circ} \mathrm{C}$ & p N.S. & N.S. & $<0.005$ \\
\hline
\end{tabular}

of a patient is read from a standard curve prepared with standard stored for 2 and 30 days at $4{ }^{\circ} \mathrm{C}$, and for 30 days at $-20^{\circ} \mathrm{C}$, values are practically identical. If the same patient's sample is read from a curve of standards stored for 3 months at $4^{\circ} \mathrm{C}$, TBG values are significantly higher $(p<0.005)$. This apparent increase of the measured TBG value is in fact due to a loss of TBG in the standard. 


\section{Discussion}

An important prerequisite for optimal radioimmunological methods is the availability of standard samples in a medium as similar as possible to the samples to be assayed. Ideally TBG standards should be dissolved in blood free of endogenous TBG. Unfortunately, this type of blood is almost impossible to obtain. Other means of prearing TBG-free blood, e.g. by charcoal adsorption or affinity chromatography, failed or were impracticable for the large amounts of specific antibody required. A further possibility would be the preparation of 'natural' standards by dilution of blood with high endogenous TBG concentrations. This alternative had to be abandoned for lack of sufficient quantities of suitable blood. In order to by-pass this situation we prepared 'artificial blood' as a diluent for the standard TBG; this diluent is readily prepared in any amount.

As observed by us and others (7), standard TBG becomes degraded in dried blood spots stored for more than one month. Thus, frequent preparation of standards was necessary, and the ready availability of a suitable diluent was of practical importance.

Since TBG also seems to be degraded in dried blood samples from patients, determinations of TBG should be carried out within one month of arrival in the laboratory.

Validity, precision and sensitivity of our blood spot assay can be considered as satisfactory: In our hands the blood spot assay seems to be even more reproducible than the plasma assay, where pipetting errors may occur due to the small plasma sample volume of $10 \mu \mathrm{l}$. In the blood spot assay, samples of equal size are easily punched out from the filter paper card.

After the introduction of neonatal thyroid screening, a relatively high incidence of TBG deficiency $(1: 7700)$ was reported in centres whose pro-

\section{References}

1. Illig, R., Torresani, T. \& Sobradillo, B. (1977) Helv. Paediat. Acta 32, 289-297.

2. Larsen, P. R. \& Broskin, K. (1975) Pediat. Res. 9, 604-609.

3. Mizuta, H., Miyai, K., Ichihara, K., Amino, N., Harada, T., Nose, O. \& Tanizawa, O. (1982) Clin. Chem. 28, 505-508.

4. Pang, S., Hotchkiss, J., Drash, A. L., Levine, L. S. \& New, M. I. (1977) J. Clin. Endocrinol. Metab. 45, 1003-1008.

5. Cacciari, E., Balsamo, A., Cassio, A., Piazzi, S., Bernardi, F., Salardi, S., Cicognani, A., Pirazzoli, P., Zappulla, F., Capelli, M. \& Paolini, M. (1982) Hormone Res. 16, 4-9.

6." Mizejewski, G. J., Bellisario, R., Beblowski, D. W. \& Carter, T. P. (1982) Clin. Chem. 28, 1207-1210.

7. Robertson, E. F., Wilkins, A.C., Oldfield, R. K. \& Pollard, A. C. (1980) J. Pediatr. 97, 604-607. grammes are based on initial thyroxine $\left(T_{4}\right)$ determinations $(9,10)$. Since TBG deficiency is a biochemical abnormality leading to low total $\mathrm{T}_{4}$ values, but without clinical implications, these children do not need treatment or follow-up examinations. TBG deficiency escape detection when screening is carried out by thyrotropin determination alone as is the case in most European countries and in Japan.

Although the establishment of this diagnosis has no consequences for the individual child, it would be interesting to know the incidence of TBG deficiency (and of TBG excess) in our population. Therefore, we have developed the TBG blood spot assay which can be carried out as easily as the screening methods for congenital hypothyroidism.

In our experience, sensitive blood spot assays of total $\mathrm{T}_{4}$ and thyrotropin have proved to be useful for monitoring optimal dosage and compliance in $\mathrm{pa}$ tients with congenital hypothyroidism under substitution therapy. The addition of the TBG assay in filter paper discs enables us not only to detẹct TBG abnormalities but also to calculate the free $\mathrm{T}_{4}$ index ( $\left.\mathrm{FT}_{4} \mathrm{I}\right)$ which correlates well with free $\mathrm{T}_{4}(11)$. Hence the determination of thyrotropin, $\mathrm{T}_{4}$ and TBG in dried blood spots allows a relatively broad evaluation of the thyroid status. It also offers a possibility for monitoring thyroid replacement therapy at shorter intervals, since no venipunctures are required and blood samples collected on filter paper cards can easily be sent to the laboratory.

The introduction of a reliable $\mathrm{TBG}$ assay in dried blood spots is a further step in the simplification of diagnostic procedures, which is of particular advantage in paediatric medicine.

\section{Acknowledgments}

The authors gratefully acknowledge the skilled technical assistance of Miss Agnes Simon.
`8. Rodbard, D. (1974) Clin. Chem. 20, 1255-1270.

9. Fisher, D. A., Dussault, J. H., Foley, T. P., Klèin, A. H., LaFranchi, S., Larsen, R. P., Mitchell, M. L., Murphey, W. H. \& Walfish, P. G. (1979) J. Pediatr. 94, 700-705.

10. Dussault, J. H. (1980) Screening for Congenital Hypothyroidism: The North American experience, In: Radioimmunoassay of Hormones, Proteins and Enzymes (Albertini A., ed.) Excerpta Medica, Amsterdam pp. 136-144.

11. Pickard, C. R., Bauer, M., Horn, K., Kubiczek, Th. \& Scriba, P. C. (1977) Internist $18,538-543$.

Dr. T. Torresani .

Universitäts-Kinderklinik

Kinderspital

Steinwiesstraße 75

CH-8032 Zürich 